\title{
EFFECT OF PHOSPHOROUS AND SULFUR FERTILIZER INTERACTION ON RICE YIELD AND YIELD ATTRIBUTES El-Ekhtyar,A. M. $^{1}$; A. A. EL-Gohary ${ }^{1}$; S. M. Bassiouni ${ }^{1}$ and A.K.M.Salem ${ }^{2} 3$ \\ 1-RRTC (Rice Research \& Training Center), Sakha, Filed Crops Research Institute, Agricultural Research Center, Egypt. \\ 2-Plant Production Department, College of Food and Agriculture Sciences, King Saud University. \\ 3-Department of Field Crops Research,National Research Center,Giza, Egypt. \\ Corresponding author mail(aelkhtyar@yahoo.com).
}

ABSTRACT

Field experiments were conducted at El-Gemmaza Station Farm, during 2012 and 2013 seasons to study the response of rice crop to phosphorous and sulfur fertilizations. Sakha 105 rice cultivar was used. The experiments were laid out in split plot design with four replications; the net plot size was $10 \mathrm{~m}^{2}$. The main plots were designated for phosphorus treatments and the sub-plots for sulfur treatments. The phosphorus treatments were $0,18,37,55 \mathrm{~kg} \mathrm{P}_{2} \mathrm{O}_{5} \mathrm{ha}^{-1}$ denote $\mathrm{P} 0, \mathrm{P} 18, \mathrm{P} 37$ and P55, while, the sulfur treatments were $0,47,95$ and $142 \mathrm{~kg} \mathrm{~S}^{-1}$ denote, S0, S47, S95 and S142.

The main results could be summarized as follows,

phosphorous application as signal significantly and positively affected rice grain yield in both seasons of study. At the same time significant improving in grain yield were detected as a results of significant improvement in yield attributes by phosphorous application. The optimum rate of $\mathrm{P}$ was $37 \mathrm{kgP}_{2} \mathrm{O}_{5} \mathrm{ha}^{-1}$ at the first season and $55 \mathrm{~kg} \mathrm{P}_{2} \mathrm{O}_{5}$ ha $^{-1}$ in the second season.

Sulfur application significantly improved growth, yield and yield attributing traits in both seasons of study. Yield and yield attributes significantly responded to sulfur fertilizer up to $95 \mathrm{~kg} \mathrm{~S} \mathrm{ha}^{-1}$ in both season and increasing sulfur rate beyond this rate slightly decreased the yield and yield components.

Regarding the interaction effect, the interaction between sulfur and phosphorous had significant effect on dry matter $\left(\mathrm{gm}^{-2}\right)$, number of tillers hill ${ }^{-1}$, Number of panicles hill ${ }^{-1}$, number of filled grains panicle ${ }^{-1}$ and grain yield tha ${ }^{-1}$ in both seasons. the optimum combination of phosphorus and sulfur was P37S95. The interaction effect on rice grain yield, in the first season, grain yield recorded its maximum value at the combination of P37S95 in the first season. It is noted that P35S95 combination occupied the second order after P55S95 without significant differences in the second season.

The combination of P37S95 could be recommended under such conditions for optimum rice grain yield.

Keywords; Rice, phosphorous, sulfur fertilizers, interaction effect.

\section{INTRODUCTION}

Intensive farming In Egypt leads to heavy withdrawal of nutrients from soils and its access depends largely upon the external application of nutrients commensurate with the nutrient uptake. 
Phosphorus $(\mathrm{P})$ is the second major element applied to rice in Egypt. Since in many soils much of the available $P$ is derived through the mineralization of organic matter, the repeated addition of $P$ fertilizer appears to be the only satisfactory way of supplying plant needs for this very important nutrient. Phosphorus is intimately associated with all life processes and thus it is a vital constituent of every living cell. This element tends to be concentrated in the seed and stimulates early root formation and growth of the plant.

Alam et al. (2009), Ehsan et al. (2009) and Zayed et al. (2010) reported that increasing phosphorous fertilizer rates up 60 to $72 \mathrm{~kg} \mathrm{P}_{2} \mathrm{O}_{5}$ ha $^{-1}$ significantly promoted growth, yield attributing characters and rice grain yield.

Deterioration in soil productivity is often observed under modern intensive cropping system especially due to deficiency of $S$ and is fast emerging an important yield limiting factor under long term rice culture (Nambiar, 1994). Sulphur (S) is a constituent of essential amino acids (cystein, methionineand cystine) involved in chlorophyll production and is thus required for protein synthesis and plant functions and structure. The effect of $S$ deficiency on yield is more pronounced during vegetative growth e.g. reduced plant height and stunted growth, reduced number of tillers, fewer and shorter panicles, reduced number of spikelets per panicle etc. Use of high analysis S-free fertilizers such as urea, triple super phosphate, muriate of potash and flooding of land causing $S$ in reduced condition for a considerable period of time result in decreased available $S$ in soil for crops. In addition to above-mentioned causes, the problem of $S$ deficiency is further aggravated where phosphate fertilizer is used abundantly. Phosphorus being a stronger anion and with relative abundance compared to $\mathrm{S}$, dislodges $\mathrm{SO}_{4}$ from the exchange sites in soils and finally making sulphate available and labile to leaching loss along with percolated water. Shehata et al. (2009), Zayed et al. (2011) and Zayed (2012) found that sulfur fertilizer at the rate of $50 \mathrm{~kg} \mathrm{~S} / \mathrm{fed}$ in the form of elemental S significantly increased rice growth, yield and yield components as well as it had apparent positive effect on soil properties.

Balanced fertilization is a pre-requisite for obtaining optimum potentiality of high yield of rice. So to increase the production of rice, it is essential to find out optimum combination of $S$ and $P$ along with other nutrients. Ali, et al. (2004), Rasavel and Ravichandran (201r) found that application of 5,10 and $20 \mathrm{~kg}$ ha- ${ }^{1}$ of $\mathrm{P}_{2} \mathrm{O}_{5}$ and $\mathrm{S}$ with recommended dose $\mathrm{N}$ and $\mathrm{K}$ found beneficial for enhancing the productivity of rice in neutral and alkali soil. An abovmentioned combination of $P$ and $S$ gave the highest values of DMP, LAI, chlorophyll content, yield attributing characteristics and yield

It is felt necessary to evaluate $S$ and $P$ requirement of rice to asses its optimum growth and achievable yield potential under the agro-climatic conditions.

With the above views and objectives in mind, the present experiment was carried out to investigate the interaction effects of $S$ and $P$ on growth and yield of Sakha 105, new high yielding variety of rice in Egypt. 


\section{MATERIALS AND METHODS}

Field experiments were conducted at El-Gemmaza Station Farm, during 2012 and 2013 seasons to study the response of rice crop to phosphorous and sulfur fertilizations. Sakha 105 (early rice cultivar 120 days from sowing to harvest) was used. Some basic properties of the soils are shown in Table 1. The experiments were laid out in split plot design with four replications; the net plot size was $10 \mathrm{~m}^{2}$. The main plots were designated for phosphorus treatments and the sub-plots for sulfur treatments. The phosphorus treatments were $0,18,37$ and $55 \mathrm{~kg} \mathrm{P}_{2} \mathrm{O}_{5}$ ha $^{-1}$ denote $\mathrm{P} 0, \mathrm{P} 18$ P37 and P55, while, the sulfur treatments were $0,47,95$ and $142 \mathrm{~kg} \mathrm{~S}^{-1}$ denote, S0, S47, S95 and S142.

Table1:Some chemical characteristics of the used soil at El-Gemmiza Station

\begin{tabular}{|l|c|c|}
\hline Tested characteristics & $\mathbf{2 0 1 2}$ & $\mathbf{2 0 1 3}$ \\
\hline $\mathrm{pH}(1: 2.5$ soil water suspension) & 7.90 & 8.13 \\
$\mathrm{Ec} \mathrm{e}_{\mathrm{e}}$ ( soil paste extracted at 25 $\mathrm{C}^{\circ} \mathrm{dS} . \mathrm{m}^{-1}$ ) & 1.46 & 2.10 \\
$\mathrm{OM}$ ( organic matter) \% & 1.82 & 1.74 \\
Soluble cations, meq..$^{-1}$ ( soil paste ): & & \\
$\mathrm{Ca}^{++}$ & 2.6 & 5.13 \\
$\mathrm{Mg}^{++}$ & 1.9 & 2.1 \\
$\mathrm{~K}^{+}$ & 0.6 & 0.7 \\
$\mathrm{Na}^{+}$ & 10.20 & 11.1 \\
$\mathrm{Soluble}^{-}$anions, meq. ${ }^{-1}$ ( soil paste ): & - & \\
$\mathrm{CO}_{3}^{-}$ & - & - \\
$\mathrm{HCO}_{3}{ }^{-}$ & 2.2 & 3.7 \\
$\mathrm{Cl}^{-}$ & 12.0 & 13.5 \\
$\mathrm{SO}_{4}^{-}$ & 1.1 & 2.5 \\
$\mathrm{Available} \mathrm{micronutrients} \mathrm{ppm} \mathrm{(EDTA)}_{\mathrm{N}}$ & & \\
$\mathrm{P}$ & 29 & 28 \\
$\mathrm{Fe}^{++}$ & 13 & 10 \\
$\mathrm{Zn}^{++}$ & 7.0 & 6.07 \\
$\mathrm{Mn}^{++}$ & 1.20 & 0.96 \\
\hline
\end{tabular}

The culture practices of rice nursery were followed according to the recommendations of Rice Research and Training Center. The fields were plowed thoroughly and dry leveled and divided into 64 plots. A basal doses of nitrogen, phosphorus and sulfur were applied in the form of urea $(46 \% \mathrm{~N})$, calcium super phosphate $\left(15.5 \% \quad \mathrm{P}_{2} \mathrm{O}_{5}\right)$ and mental sulfur $(98 \% \mathrm{~S})$, respectively. The whole of phosphorus and sulfur treatments were applied before plowed and 2/3 of recommended nitrogen $\mathrm{kg} \mathrm{N}^{-1}$ ) was applied at the time of rice transplanting and the remaining $1 / 3$ of nitrogen was applied at 30 days after rice transplanting, $24 \mathrm{~kg} \mathrm{ha}^{-1} \mathrm{Zn} \mathrm{So}_{4}$ was a immediately applied after puddling. Sakha 105 rice cultivar was planted in May, $1^{\text {st }}$ in both 
seasons and transplanted after 30 days from sowing at the rate of 3-4 seedlings hill $^{-1}$ with spacing of $20 * 20 \mathrm{~cm}$.

At heading, plant samples were randomly taken, transferred to lab and then growth parameters i.e., dry matter production $\left(\mathrm{gm}^{-2}\right)$, leaf area index, chlorophyll content (SPAD value) and heading date (days) were recorded.

At harvest, plant height $(\mathrm{cm})$, number of tillers hill $^{-1}$, number of panicles hill $^{-1}$, yield and yield components i.e., panicle length $(\mathrm{cm})$, number of filled grains panicle ${ }^{-1}$, number of unfilled grains panicle ${ }^{-1}$, fertility percent (\%), 1000grain weight $(\mathrm{g})$, grain yield $\mathrm{t} \mathrm{ha}^{-1}$ biological yield $\mathrm{t} \mathrm{ha}^{-1}$ and harvest index data were assessed.

Data were analyzed by the following analysis of variance (IRRISTAT) described by Gomez and Gomez,(1984).Differences among treatment means were compared by least significant difference (LSD), for mean separations, LSD values were used at $\mathrm{P}<0.05$.

\section{RESULTS AND DISCUSSIONS}

Effect of phosphorus and sulfur on growth and yield of rice is furnished in Tables 2, 3, 4 and 5. The results showed that the application of $P$ and $S$ fertilizer significantly influenced all growth characteristics and yield and its components as compared with control treatment. The interaction of $P$ and $\mathrm{S}$ showed significantly effect in dray matter $\left(\mathrm{gm}^{-2}\right)$, number of tillers hill $^{-1}$, number of panicles hill ${ }^{-1}$, number of filled grains panicle ${ }^{-1}$ and grain yield in both season of study (Table 6).

\section{Effect of phosphorous:}

The growth, yield attributes and yield of rice were significantly influenced by addition of $P$ over control as single. Increasing phosphorous $(P)$ rate significantly boosted all studied growth traits, yield attributes and grain yield as well as harvest index in both seasons (Tables 2, 3, 4 and 5). Raising $P$ rates significantly elevated yield and yield components in both years of study. The recorded increments owing to $P$ rates were fact and significant up to the rate of $37 \mathrm{~kg} \mathrm{P}_{2} \mathrm{O}_{5}$ ha $^{-1}$. At the higher $\mathrm{P}$ rate of $55 \mathrm{~kg} \mathrm{P}_{2} \mathrm{O}_{5}$ ha $^{-1}$, slight reduction was observed without significant reduction.

Regarding the effect of $\mathrm{P}$ rate on dry matter, the dry matter production increased significantly with increasing rate of $P$ up to $37 \mathrm{~kg} \mathrm{P}_{2} \mathrm{O}_{5}$ $\mathrm{ha}^{-1}$ in the first season and $55 \mathrm{~kg} \mathrm{P}_{2} \mathrm{O}_{5} \mathrm{ha}^{-1}$ in the second season (Table 2). The highest dry matter was observed in $37 \mathrm{~kg} \mathrm{P}_{2} \mathrm{O}_{5} \mathrm{ha}^{-1}$ in the first season and $55 \mathrm{~kg} \mathrm{P}_{2} \mathrm{O}_{5}$ ha $^{-1}$ without any significant differences with $37 \mathrm{~kg} \mathrm{P}_{2} \mathrm{O}_{5}$ ha $^{-1}$ in the second season.

The leaf area index and chlorophyll content increased up to $37 \mathrm{~kg}$ $\mathrm{P}_{2} \mathrm{O}_{5}$ ha $^{-1}$ and thereafter, decreased (Table 2). Increasing level of $\mathrm{P}$ application may increased dry matter production is the resultant of better growth and higher number of tillers which resulted in high photosynthetic actively and formation of more photosynthetic (Sarika et al., 2006).Furthermore, phosphorous application might be improved root growth, pushing early growth and nutrient uptake as well as improved soil properties resulted in apparent height growth giving high dry matter and large level area. 
Phosphorous also improved and increased chlorophyll formation owing to increase ATP compound of energy.

Data in Table 3 showed that heading date was not significantly influenced by $P$ levels as it mostly governed by genetic make up of the variety. Plant height, number of tillers hill ${ }^{-1}$ and number of panicles hill ${ }^{-1}$ increased with the application rate of $\mathrm{P}$ up to $37 \mathrm{~kg} \mathrm{P}_{2} \mathrm{O}_{5} \mathrm{ha}^{-1}$ and thereafter declined.

$P$ treatments significantly increased panicle length, number of filled grains panicle $e^{-1}$ and fertility and deceased number of unfilled grains panicle ${ }^{-1}$ as compared with control treatment in both season of study (Table 4). The longest panicle length was observed in $37 \mathrm{~kg} \mathrm{P}_{2} \mathrm{O}_{5} \mathrm{ha}^{-1}$ while the highest filled grains panicle ${ }^{-1}$ was obtained with $37 \mathrm{~kg} \mathrm{P}_{2} \mathrm{O}_{5} \mathrm{ha}^{-1}$ in the first season and $55 \mathrm{P}_{2} \mathrm{O}_{5} \mathrm{ha}^{-1}$ in the second season. The lowest number of unfilled grains panicle ${ }^{-1}$ was observed in $37 \mathrm{P}_{2} \mathrm{O}_{5}$ ha $^{-1}$, while the highest fertility percent was observed in in37 $\mathrm{P}_{2} \mathrm{O}_{5}$ ha $^{-1}$.

Data in Table 5 showed that the application of $\mathrm{P}$ significantly influenced 1000- grain weight, biological yield, grain yield and harvest index compared with control treatment. The highest values of 1000- grain weight and biological yield were observed in $55 \mathrm{P}_{2} \mathrm{O}_{5}$ ha $^{-1}$, while the highest grain yield and harvest index was obtained with $37 \mathrm{~kg} \mathrm{P}_{2} \mathrm{O}_{5} \mathrm{ha}^{-1}$ in the first season and $55 \mathrm{P}_{2} \mathrm{O}_{5}$ ha $^{-1}$ in the second season.

Increasing phosphorus doses significantly increased yield and harvest index over control. High doses of $\mathrm{P}$ might have accelerated growth and brought about higher production of grain yield (Rao and Shukla, 1992).

\section{Effect of sulfur:}

Elaborated traits; growth, yield attributes and yield significantly and positively affected by sulfur fertilizer. The dry matter production, LAI, chlorophyll content, plant height, number of tillers and number of panicles increased significantly with the increasing rate of $S$ up to $95 \mathrm{~kg} \mathrm{~S} \mathrm{ha}^{-1}$ and thereafter declined at higher level of sulfur. These results were partially agreement of Islam et al. (1990). The heading date was not significantly influenced by $S$ levels (Tables 2 and 3 ).

The single effect of sulfur on yield and yield attributes were significant and the highest values of panicle length, number of filled grain, fertility percent, 1000-grain weight, biological yield, grain yield and harvest index were obtained with $95 \mathrm{~kg} \mathrm{~S} \mathrm{ha}^{-1}$ (Tables 4 and 5). On the other hand, the lowest values of them were observed in control treatment in both seasons. The increase in yield may be attributed to the favorable effect of sulfur availability to plants improving soil properties, protein synthesis, improve growth parameters, photosynthesis and assimilates resulted in improving yield attributes leading to higher grain yield (Ram et al., 1999).

The single effect of $S$ on grain yield was significant and the highest grain yield was obtained with S95 treatment (Table 5). Increase in grain yield due to $S$ application was reported by Zayed et al. (2011) and Zayed (2012). 
Table 2: Dry matter $\left(\mathrm{gm}^{-2}\right)$, LAl and chlorophyll content (SPAD value) of rice affected by phosphorous and sulfur rates during 2012 and 2013 seasons.

\begin{tabular}{|c|c|c|c|c|c|c|}
\hline \multirow{2}{*}{\begin{tabular}{|l|} 
Characters \\
Treatments \\
\end{tabular}} & \multicolumn{2}{|c|}{ Dray matter $\left(\mathrm{gm}^{-2}\right)$} & \multicolumn{2}{|c|}{ LAI } & \multicolumn{2}{|c|}{ chlorophyll content } \\
\hline & 2012 & 2013 & 2012 & 2013 & 2012 & 2013 \\
\hline $\mathrm{P}$ levels $\mathrm{kg} / \mathrm{ha}$ & & & & & & \\
\hline 0 & 1300.6 & 1545 & 5.36 & 5.74 & 38.94 & 38.99 \\
\hline 18 & 1472.8 & 1552 & 6.10 & 6.00 & 42.57 & 43.02 \\
\hline 37 & 1510.6 & 1628 & 6.27 & 6.34 & 42.62 & 43.70 \\
\hline 55 & 1500.8 & 1683 & 5.98 & 6.24 & 41.85 & 42.40 \\
\hline F test & ** & ** & * & * & * & * \\
\hline LSD at 0.05 & 111.2 & 55.9 & 0.39 & 0.20 & 2.11 & 1.37 \\
\hline $\begin{array}{l}\text { S levels kg/ha } \\
0\end{array}$ & 1306.2 & 1472 & 5.45 & 5.70 & 38.88 & 39.93 \\
\hline 47 & 1520.4 & 1617 & 6.20 & 6.07 & 42.37 & 42.12 \\
\hline 95 & 1544.2 & 1685 & 6.26 & 6.33 & 43.11 & 43.89 \\
\hline 142 & 1414.0 & 1634 & 5.80 & 6.23 & 41.63 & 42.17 \\
\hline $\mathrm{F}$ test & ** & $\star \star *$ & ** & ** & ** & ${ }^{\star *}$ \\
\hline LSD at 0.05 & 68.8 & 48.77 & 0.34 & 0.24 & 2.39 & 1.68 \\
\hline Interaction & ** & ** & NS & NS & NS & NS \\
\hline
\end{tabular}

$\mathrm{NS},{ }^{* *}$ and ${ }^{*}$ respectively non significant, significant in $1 \%$ and $5 \%$ levels of probability.

Table 3: Heading date (days), plant height $(\mathrm{cm})$, number of tillers hill ${ }^{-1}$ and number of panicle hill ${ }^{-1}$ of rice affected by phosphorous and sulfur rates during 2012and 2013 seasons.

\begin{tabular}{|c|c|c|c|c|c|c|c|c|}
\hline \multirow{2}{*}{\begin{tabular}{|l|} 
Characters \\
Treatments \\
\end{tabular}} & \multicolumn{2}{|c|}{$\begin{array}{l}\text { Heading date } \\
\text { (days) }\end{array}$} & \multicolumn{2}{|c|}{$\begin{array}{l}\text { Plant height } \\
(\mathbf{c m})\end{array}$} & \multicolumn{2}{|c|}{$\begin{array}{l}\text { No. of tillers } \\
\text { hill }^{-1}\end{array}$} & \multicolumn{2}{|c|}{$\begin{array}{c}\text { No. of panicles } \\
\text { hill }^{-1}\end{array}$} \\
\hline & 2012 & 2013 & 2012 & 2013 & 2012 & 2013 & 2012 & 2013 \\
\hline $\mathrm{P}$ levels $\mathrm{kg} / \mathrm{ha}$ & & & & & & & & \\
\hline 0 & 91.00 & 91.75 & 98.2 & 103.7 & 21.58 & 21.38 & 20.08 & 19.31 \\
\hline 18 & 91.65 & 91.63 & 100.5 & 109.6 & 22.17 & 21.75 & 20.91 & 20.38 \\
\hline 37 & 91.45 & 90.94 & 103.2 & 110.9 & 22.38 & 22.63 & 21.19 & 20.69 \\
\hline 55 & 91.83 & 90.60 & 102.3 & 112.2 & 22.03 & 22.00 & 20.84 & 20.75 \\
\hline $\mathrm{F}$ test & NS & NS & * & ** & * & $\star *$ & $\star *$ & * \\
\hline LSD at 0.05 & - & - & 3.07 & 1.36 & 0.46 & 0.65 & 0.38 & 0.62 \\
\hline $\begin{array}{l}\text { S levels } \mathrm{kg} / \mathrm{ha} \\
0\end{array}$ & 91.63 & 90.94 & 99.4 & 108.2 & 20.65 & 20.81 & 19.63 & 19.13 \\
\hline 47 & 91.13 & 91.13 & 100.6 & 108.6 & 22.77 & 22.00 & 21.39 & 20.19 \\
\hline 95 & 91.70 & 91.75 & 102.5 & 110.1 & 23.00 & 23.06 & 21.59 & 21.19 \\
\hline 142 & 91.08 & 91.13 & 101.6 & 109.5 & 21.81 & 21.88 & 20.41 & 20.63 \\
\hline F test & NS & NS & $\star *$ & * & ** & ** & ** & ** \\
\hline LSD at 0.05 & $\cdots$ & - & 1.69 & 1.26 & 0.67 & 0.61 & 0.56 & 0.53 \\
\hline interaction & NS & NS & NS & NS & $\star \star *$ & $\star \star *$ & $\star *$ & $\star \star *$ \\
\hline
\end{tabular}

NS, ${ }^{\star *}$ and ${ }^{*}$ respectively non significant, significant in $1 \%$ and $5 \%$ levels of probability. 
Table 4: Panicle length $(\mathrm{cm})$, number of filled grains panicle ${ }^{-1}$ and number of unfilled grains panicle $e^{-1}$ and fertility percent of rice as affected by phosphorous and sulfur rates during 2012and 2013 seasons.

\begin{tabular}{|c|c|c|c|c|c|c|c|c|}
\hline \multirow{2}{*}{\begin{tabular}{|l|} 
Characters \\
Treatments \\
\end{tabular}} & \multicolumn{2}{|c|}{$\begin{array}{l}\text { Panicle length } \\
(\mathrm{cm})\end{array}$} & \multicolumn{2}{|c|}{$\begin{array}{c}\text { No. of filled } \\
\text { grains panicle }^{-1}\end{array}$} & \multicolumn{2}{|c|}{$\begin{array}{l}\text { No. of unfilled } \\
\text { grains panicle }^{-1}\end{array}$} & \multicolumn{2}{|c|}{$\begin{array}{c}\text { Fertility percent } \\
(\%)\end{array}$} \\
\hline & 2012 & 2013 & 2012 & 2013 & 2012 & 2013 & 2012 & 2013 \\
\hline $\mathrm{P}$ levels kg/ha & & & & & & & & \\
\hline 0 & 21.84 & 21.88 & 106.3 & 140.5 & 12.44 & 8.75 & 89 & 94 \\
\hline 18 & 22.03 & 22.44 & 111.7 & 141.1 & 8.06 & 9.94 & 93 & 93 \\
\hline 37 & 22.13 & 22.56 & 112.6 & 145.9 & 7.44 & 7.44 & 94 & 95 \\
\hline 55 & 21.97 & 22.44 & 108.0 & 148.0 & 10.5 & 7.88 & 91 & 95 \\
\hline $\mathrm{F}$ test & NS & $\star \star$ & ** & * & $* *$ & $\star \star$ & $\star *$ & ** \\
\hline LSD at 0.05 & & 0.35 & 3.57 & 6.7 & 2.22 & 0.69 & 0.02 & 0.02 \\
\hline S levels $\mathrm{kg} / \mathrm{ha}$ & 2169 & 2225 & 1056 & 1408 & 1106 & 944 & 91 & 94 \\
\hline 47 & 22.13 & 22.38 & 111.4 & 142.9 & 8.50 & 7.94 & 93 & 95 \\
\hline 95 & 22.22 & 22.63 & 113. & 146.6 & 8.88 & 6.81 & 93 & 96 \\
\hline 142 & 21.94 & 22.06 & 108.5 & 145.1 & 10.00 & 9.81 & 92 & 94 \\
\hline $\mathrm{F}$ test & $*$ & $*$ & $\star *$ & $*$ & $*$ & $\star \star$ & $\star *$ & $* *$ \\
\hline LSD at 0.05 & 0.47 & 0.50 & 3.35 & 4.25 & 1.87 & 1.83 & 0.01 & 0.01 \\
\hline Interaction & NS & NS & $\star *$ & $\star \star$ & NS & NS & NS & NS \\
\hline
\end{tabular}

NS, ${ }^{* *}$ and ${ }^{*}$ respectively non significant, significant in $1 \%$ and $5 \%$ levels of probability.

Table 5: 1000-grain weight $(\mathrm{g})$, biological yield $\left(\mathrm{t} \mathrm{ha}^{-1}\right)$, grain yield $\left(\mathrm{t} \mathrm{ha} \mathrm{h}^{-1}\right)$ and harvest index of rice as affected by phosphorous and sulfur rates during 2012and 2013 seasons.

\begin{tabular}{|c|c|c|c|c|c|c|c|c|}
\hline \multirow{2}{*}{\begin{tabular}{|l|} 
Characters \\
Treatments \\
\end{tabular}} & \multicolumn{2}{|c|}{$\begin{array}{c}\text { 1000-grain weight } \\
(\mathrm{g})\end{array}$} & \multicolumn{2}{|c|}{$\begin{array}{c}\text { Biological yield (t } \\
\left.h^{-1}\right)\end{array}$} & \multicolumn{2}{|c|}{$\begin{array}{c}\text { Grain yield } \\
\left(\mathrm{t} \mathrm{h}^{-1}\right)\end{array}$} & \multicolumn{2}{|c|}{ Harvest index } \\
\hline & 2012 & 2013 & 2012 & 2013 & 2012 & 2013 & 2012 & 2013 \\
\hline $\mathrm{P}$ levels kg/ha & & & & & & & & \\
\hline 0 & 28.19 & 28.13 & 23.48 & 25.25 & 8.13 & 9.66 & 0.35 & 0.38 \\
\hline 18 & 28.37 & 28.78 & 24.15 & 25.88 & 9.21 & 9.70 & 0.38 & 0.38 \\
\hline 37 & 28.73 & 29.06 & 24.90 & 26.06 & 9.44 & 10.18 & 0.38 & 0.39 \\
\hline 55 & 29.19 & 29.53 & 25.13 & 26.56 & 9.38 & 10.52 & 0.37 & 0.40 \\
\hline F test & * & $\star \star$ & $\star \star$ & $\star \star$ & ** & $\star \star \star *$ & * & * \\
\hline LSD at 0.05 & 0.66 & 0.41 & 0.89 & 0.84 & 0.39 & 0.34 & 0.02 & 0.01 \\
\hline S levels kg/ha & & & & & & & & \\
\hline & 28.03 & 28.69 & 23.63 & 25.50 & 81.6 & 9.20 & 0.35 & 0.36 \\
\hline 47 & 28.91 & 28.88 & 24.53 & 26.00 & 9.36 & 10.11 & 0.38 & 0.39 \\
\hline 95 & 28.81 & 29.09 & 25.13 & 26.31 & 9.80 & 10.53 & 0.39 & 0.40 \\
\hline 142 & 28.73 & 28.84 & 24.38 & 25.94 & 8.84 & 1021 & 0.36 & 0.39 \\
\hline F test & $* *$ & * & * & * & $* *$ & $\star *$ & 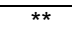 & * \\
\hline LSD at 0.05 & 0.45 & 0.35 & 0.88 & 0.63 & 0.23 & 0.30 & 0.02 & 0.01 \\
\hline Interaction & NS & NS & NS & NS & $* *$ & $\star \star *$ & NS & NS \\
\hline
\end{tabular}

NS, ${ }^{* *}$ and ${ }^{*}$ respectively non significant, significant in $1 \%$ and $5 \%$ levels of probability.

The interaction effect

Data furnished in Table 6 pointed out that the interaction between $P$ and $S$ had significant effect on dry matter production $\left(\mathrm{gm}^{-2}\right)$, number of tillers hill $^{-1}$, number of panicles hill ${ }^{-1}$, number of filled grains panicle ${ }^{-1}$ and grain yield $\left(\mathrm{t} \mathrm{ha} \mathrm{C}^{-1}\right.$ ) in both seasons of study. The highest dry matter was obtained in P37S47 which was statistically similar to P18S47, P18S95, P37S95, P55S47 and P55S95 in the first season while, P55S95 was the highest without any 
significant difference with P55S47 in the second season. Obviously, the optimum combination of phosphorus and sulfur was P37S95. The later combination gave the highest values of number of tillers and number of filled grains panicle ${ }^{-1}$ in both seasons, while, the highest value of number of panicle ${ }^{-1}$ was obtained with P37S95 in the first season and P55S95 in the second season (Table 6). On the other hand, the lowest values of dray matter $\left(\mathrm{gm}^{-2}\right)$, number of tiller hill ${ }^{-1}$ and panicle numbers hill ${ }^{-1}$ were recorded when rice plants didn't receive any of $\mathrm{P}$ or $\mathrm{S}$ in the first and second seasons.

Table 6: Dry matter $\left(\mathrm{gm}^{-2}\right)$, number of tillers hill ${ }^{-1}$ and number of panicle hill $^{-1}$, number of filled grains panicle ${ }^{-1}$ and grain yield rice as affected by the interaction between phosphorous and sulfur rates during 2012and 2013 seasons.

\begin{tabular}{|c|c|c|c|c|c|c|c|c|c|c|}
\hline \multirow{2}{*}{$\begin{array}{l}\text { Characters } \\
\text { Treatments }\end{array}$} & \multicolumn{2}{|c|}{$\begin{array}{l}\text { Dray matter } \\
\left(\mathrm{gm}^{-2}\right)\end{array}$} & \multicolumn{2}{|c|}{ 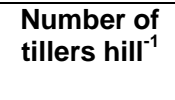 } & \multicolumn{2}{|c|}{$\begin{array}{c}\text { Number of } \\
\text { panicles hill }^{-1}\end{array}$} & \multicolumn{2}{|c|}{$\begin{array}{l}\text { Number of } \\
\text { filled grains } \\
\text { panicle }^{-1}\end{array}$} & \multicolumn{2}{|c|}{$\begin{array}{l}\text { Grain yield } \\
\qquad\left(t^{-1}\right)\end{array}$} \\
\hline & 2012 & 2013 & 2012 & 2013 & 2012 & 2013 & 2012 & 2013 & 2012 & 2013 \\
\hline POSO & 1164.7 & 1360 & 20.13 & 19.25 & 18.50 & 17.50 & 100.0 & 134.8 & 7.28 & 8.50 \\
\hline & 1 & 560 & 21.45 & 21.25 & 19.95 & 18.50 & 101.5 & 136.8 & 8.02 & 9.75 \\
\hline P0S95 & 1411.2 & 1600 & 22.00 & 22.50 & 20.50 & 20.50 & 107.8 & 146.8 & 8.82 & 10.00 \\
\hline P0S142 & 1344.0 & 1660 & 22.75 & 22.50 & 21.38 & 20.75 & 116.0 & 143.8 & 8.40 & 10.38 \\
\hline P18S0 & 1260.0 & 1452 & 20.50 & 20.50 & 19.50 & 19.00 & 107.5 & 141.0 & 7.88 & 9.08 \\
\hline P18S47 & 1579.2 & 1560 & 23.38 & 21.50 & 21.88 & 20.25 & 116.8 & 141.0 & 9.87 & 9.75 \\
\hline P18S95 & 1596.0 & 1636 & 23.50 & 23.25 & 21.88 & 21.25 & 114.5 & 146.5 & 9.98 & 10.23 \\
\hline P18S142 & 1456.0 & 1560 & 21.25 & 21.75 & 20.38 & 21.00 & 108.0 & 135.8 & 9.10 & 9.75 \\
\hline P37SC & 1400.0 & 1524 & 20.88 & 21.75 & 19.88 & 19.5 & 106.8 & 142.5 & 8.75 & 9.53 \\
\hline P37S47 & 1640.8 & 1608 & 23.38 & 22.75 & 22.00 & 20.50 & 115.5 & 146.0 & 9.66 & 10.05 \\
\hline P37S95 & 1545.6 & 1720 & 23.75 & 23.50 & 22.50 & 21.25 & 117.8 & 149.7 & 10.41 & 10.75 \\
\hline P37S142 & 1456.0 & 1660 & 21.50 & 22.50 & 20.38 & 21.50 & 110.3 & 147.0 & 9.10 & 10.38 \\
\hline P55 & 1400.0 & 1552 & 20.75 & 21.75 & 20.63 & 20.50 & 108.0 & 145.0 & 8.75 & 9.70 \\
\hline P55 & 1579.2 & 1740 & 22.88 & 22.5 & 21.75 & 21.50 & 112.0 & 148.0 & 9.87 & 10.88 \\
\hline & 1624.0 & 1784 & 22.75 & 23.00 & 21.50 & 21.75 & 109.0 & 148.0 & 10.00 & 11.15 \\
\hline P55S142 & 1400.0 & 1656 & 21.75 & 20.75 & 19.50 & 19.25 & 103.0 & 149.6 & 8.75 & 10.35 \\
\hline LSD at0.05 & 137.6 & 97.5 & 1.14 & 1.11 & 1.13 & 1.07 & 6.7 & 8.5 & 0.3 & 0.50 \\
\hline
\end{tabular}

.It was noted that the higher sulfur rate of $142 \mathrm{~kg} \mathrm{~S} \mathrm{ha}^{-1}$ at any rates of phosphorous of $18,37,55 \mathrm{~kg} \mathrm{P}_{2} \mathrm{O}_{5} \mathrm{ha}^{-1}$ significantly reduced the panicle and tiller numbers hill ${ }^{-1}$ that was fact in both seasons. As for, number of filled grains panicle ${ }^{-1}$ the combination of P37S95 was optimum in both seasons. The combination P35S95 gave the highest values of filled grains without significant differences with those produced by most combinations in both seasons.

Regarding the interaction effect on rice grain yield, in the first season, grain yield recorded its maximum value at the combination of P37S95. It is noted that P55S95 combination occupied the second order after P37S95. That was matching with signal effect of phosphorous in first season. Furthermore, the data in table1 indicated that the available $\mathrm{P}$ in the experimental field was fairly sufficient. In addition, the synergism effect was very clear since, adding $P$ in the form of calcium super phosphate reduced the rate of sulfur comparing to adding sulfur as signal element as listed in tables 4 and 5. In the second season, The combination of P55S95 gave the highest value of rice grain yield without any significant differences with those produced by P55S47and P37S95. The last finding proved that Increasing P 
rate reduce needed $S$ rate since the calcium super phosphate contains around $26 \%$ of sulfur. Interestingly, the combinations of P55S47, P37S95 and P37S142 were at a par regarding grain yield in the second season. At the same time, P0S142 and P37S95 gave the similar value of grain yield supporting synergism effect between $\mathrm{P}$ and $\mathrm{S}$ elements. As cited here the positive effect of $P$ on rice grain yield might be manly attributed to it role in improving yield components of rice such as panicle number, filled grains panicle $^{-1}$, and panicle weight . The positive $P$ effect on mentioned yield components might be contributed to improving dry matter production, photosynthesis rate during vegetative and productive stages as well as metabolism process and assimilate translocations. The latter mentioned desired effect of $P$ might be due to it effective role in increasing $P$ content leading to raising plant content of ATP, nucleic acid, NADPH and FADPH and root formation. Sulfur application also showed better rice yield as result of improving yield components of rice such as main ones of panicle number, filled grains of panicle and panicle weight resulted din higher grain yield owing to sulfur application. The favorable effect of sulfur application mainly attributed to encourage nutrients uptake, increasing amino acids content involved in chlorophyll production, and protein synthesis. The latter effect of sulfur might be improved plant functions and structure. Furthermore, improving the previous mentioned items might proved considerable improvements in photosynthesis rate, assimilates products and its translocation to panicle as well as maximizing its contribution in rice grain yield formation. In addition, sulfur application might keep high content of nitrogen and protein contents at late growth stage resulted in high current photosynthesis leading to improving rice grain filling and high grain yield. Similar results had been reported by Ali, et al. (2004) and Rasavel and Ravichandran(201ॅ).

\section{CONCLUSION}

The results showed that the application of $\mathrm{P}$ and $\mathrm{S}$ fertilizer significantly influenced all growth characteristics and yield and its components compared with control treatment. It was also confirmed that the combination P37S95 performed the best result regarding growth, yield and yield attributes.

\section{REFERNCES}

Alam, M.M.; M.H.Ali; A. K.M.Amin and M.Hasanuzzaman(2009). Yield attributes, yield and harvest index of three rice varieties under different levels of phosphorous. Advances in Biological Res., 3(3-4):132-139.

Ali, M.M.; M.S. Mian; A. Islam; J.A. Begum and A.K.M. Ferdous (2004). Interaction effects of sulphur and phosphorus on Wetland Rice. Asian J. of Plant Sci., 3: 597-601. 
Ehsan, U.; A. Rehman; Q. Arshad and S.S. Shah(2009). Yield response of fine rice to NP fertilizer and weed management practices. Pakistan J. Bot.,41(3):1351-1357.

Gomez, K.A. and A.A Gomez (1984). Statistical procedures for agricultural research. $2^{\text {nd }}$ ed. John Wiley and sons, New York, USA.

Islam, M.R.; M.S. Hoque and Z.H. Bhaiya (1990). Effect of nitroigen and sulphur fertilization on yield response of nitrogen and sulphur composition of rice. Bangladesh J. Agric. Sci., 17(2):299-302.

Nambiar, K.K.M. (1994). Soil fertility and crop productivity under long-term fertilizer use in India. ICAR Publication, New Delhi, pp. 149.

Rasavel, M. and M. Ravichandran (2013). Effect of zinc, phosphorous and sulfur interactions on growth and yield of rice under neutral and alkaline soils. International J. of Current Res., 5 (1): 65-67.

Ram, H.; S. Singh and C.N. Chaubey (1999). Response of rice to sulphur under reclaimed salt affected soil. Oryza, 36(3): 272-273.

Roa, C.P. and D.N. Shukla (1992). Interaction of $\mathrm{Zn}$ with different source and levels of phosphorus on growth and yield of rice. Oryza, 34(3): 229233.

Sarika V. Sune; R.M. Deshpande Khawale; P.V. Banskar and Bhavita P. Gurav (2006). J. Soils and Crops, 16(1): 217-221.

Shehata, S.M.; B. A. Zayed ; E. S. Naeem ; S. E.Seedex and A. A. Gohary (2009) Response of rice ( Oryaza sativa L.)to different levels of Zinc and Sulfur fertilizer under saline soil. Egypt. J. of Appl. Sci., 24(12B): 551-565.

Zayed, B. A. (2012). Efficiency of different sulfur fertilizer sources in increasing hybrid rice productivity under saline soil conditions. Egypt. J. of Agric. Res., 90 (4):275-288

Zayed, B.A.; E.S.Naeem; H.M.El Sharkawi and E.E.Gewaily (2011). Efficiency of sulfur fertilizer on yield and soil properties of salt stressed paddy fields. Egypt. J. Agric. Res., 88 (1):1-11.

Zayed, B.A. ; I.S. El-Rafaee and S.E.M. Sedeek (2010). Response of different rice varieties to phosphorus fertilizer under newly reclaimed saline soils. J. of Plant Production, Mansoura Univ.,1 (11): 1479-1493. 
تاثير التفاعل بين الفففور و الكبريت علي محصول الحبوب ومكوناتة في الأرز.

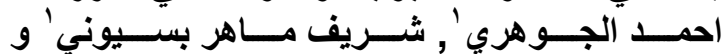

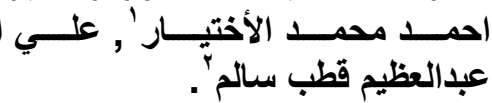

ا-مركز البحوث والتدريب في الأزز- سخا ـ معهد بحوث المحاصيل الحقليه ـ مركز البحوث الزراعيه ـ

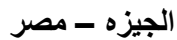

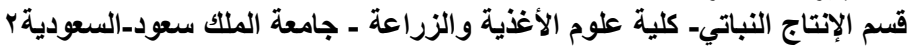

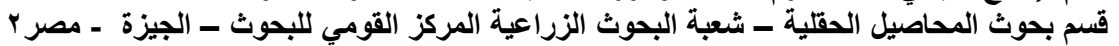

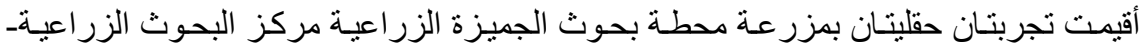

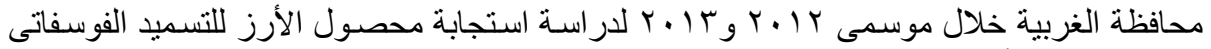

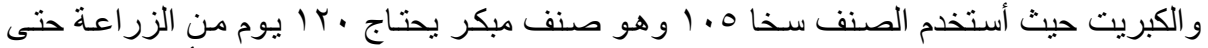

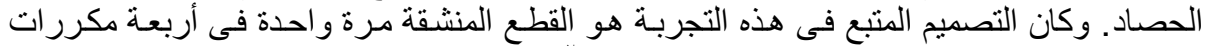

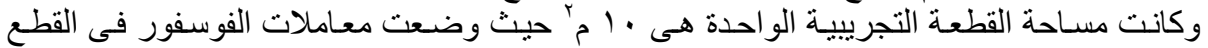

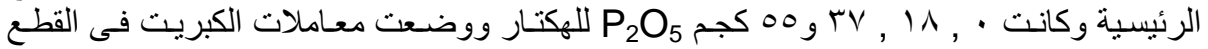

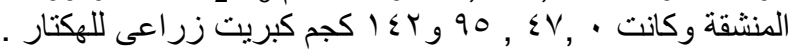

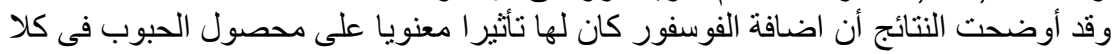

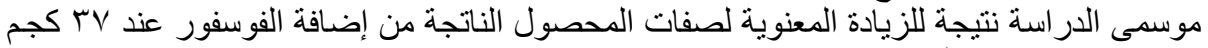

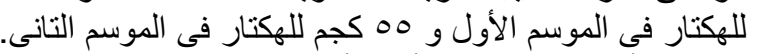

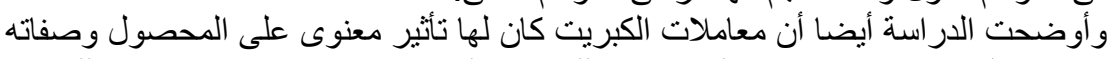

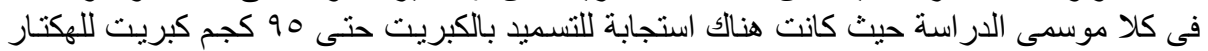

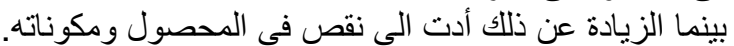

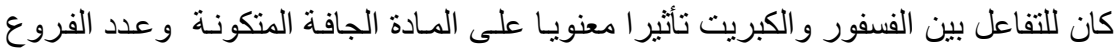

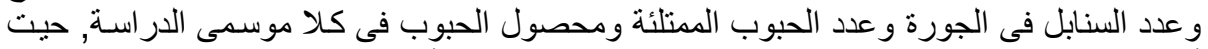

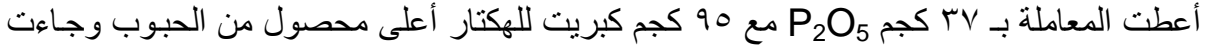
بعدها المعاملة بـ 00 كجم

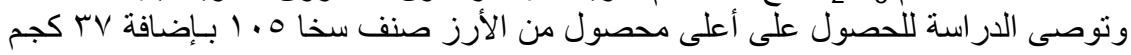
Pع 90 مجم كبريت للهكتار وذللك تحت ظروف هذه الدر اسة.

كلية الزراعة - جامعة المنصورة

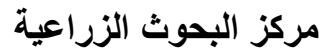

قام بتحكيم البحث

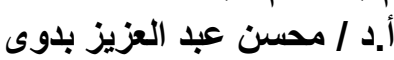

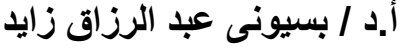

